\title{
Efficacy of fenpyroximate (METI acaricides) in the control of fruit tree European red mite (Panonychus ulmi, Koch) in selected apple orchards in Poland
}

\author{
Skuteczność fenpiroksymatu (METI akarycydy) w zwalczaniu \\ przędziorka owocowca (Panonychus ulmi, Koch) \\ w wybranych sadach jabłoniowych w Polsce
}

Damian Gorzka*, Michał Hołdaj, Grażyna Soika

\section{Summary}

European red mite (Panonychus ulmi, Koch) is an important pest of apple orchards. Some of the commonly used acaricides against this folivore pest are those from the METI group (mitochondrial electron transport inhibitors). The aim of the study was to evaluate the efficacy of fenpyroximate (active substance of product Ortus $05 \mathrm{SC}$ ) in the control of fruit tree European red mite. The sensitivity of fruit tree European red mite to this active substance was determined in laboratory conditions. As a result of the conducted research, reduced susceptibility of fruit tree European red mite to fenpyroximate was found in three out of six studied populations of this mite in apple orchards located in central Poland.

Key words: sensitivity, acaricides, phytophagous mites, apple tree

\section{Streszczenie}

Przędziorek owocowiec (Panonychus ulmi, Koch) jest ważnym szkodnikiem sadów jabłoniowych. Powszechnie stosowanymi akarycydami do zwalczania tego fitofaga są preparaty z grupy METI (inhibitory mitochondrialnego transportu elektronów). Celem badań była ocena skuteczności fenpiroksymatu (substancja czynna środka Ortus $05 \mathrm{SC}$ ) w zwalczaniu przędziorka owocowca. Wrażliwość osobników przędziorka owocowca na tę substancję czynną określono w warunkach laboratoryjnych. W wyniku przeprowadzonych badań, obniżoną wrażliwość przędziorka owocowca na fenpiroksymat stwierdzono w trzech spośród sześciu badanych populacji tego roztocza w sadach jabłoniowych zlokalizowanych w Polsce centralnej.

Słowa kluczowe: wrażliwość, akarycydy, roślinożerne roztocze, jabłoń

Instytut Ogrodnictwa

Konstytucji 3 Maja 1/3, 96-100 Skierniewice

*corresponding author: damian.gorzka@inhort.pl

ORCID: 0000-0003-2300-4517 


\section{Wstęp / Introduction}

Roślinożerne roztocze stanowią jedną z najbardziej licznych i powszechnych grup szkodników w sadach jabłoniowych (Putman 1955; Van se Vrie i wsp. 1985). Do najbardziej znanych roztoczy, które możemy zaobserwować w sadach jabłoniowych, obok przędziorka chmielowca (Tetranychus urticae, Koch) należy przędziorek owocowiec (Panonychus ulmi, Koch) (McMurtry i wsp. 1970; Van se Vrie i wsp. 1985; Marshall i Pree 1991). Szybki rozwój i duża płodność przędziorka owocowca sprawiają, że szkodnik ten powoduje często znaczne straty w sadach jabłoniowych. W warunkach klimatycznych Polski roztocz ten tworzy w sezonie wegetacyjnym od 4 do 5 pokoleń. Dynamiczny wzrost jego liczebności ma miejsce w okresie od czerwca i lipca, ale w znacznym stopniu uzależniony jest to od przebiegu warunków pogodowych. Po deszczowej i chłodnej pogodzie w pierwszej połowie lata, przędziorek owocowiec najliczniej występuje w sierpniu i we wrześniu (Łabanowska i wsp. 2017). W celu zredukowania populacji przędziorka owocowca często konieczne jest wykonanie kilku zabiegów w sezonie wegetacyjnym (Maciesiak i Olszak 2010).

Powszechnie stosowanymi akarycydami przeciwko ruchomym stadiom $P$. ulmi są środki z grupy METI (inhibitory mitochondrialnego transportu elektronów). Jednak, wieloletnie i wielokrotne opryskiwanie preparatami o takim samym mechanizmie działania może doprowadzić do selekcji ras odpornych szkodnika na stosowane przeciwko niemu środki ochrony roślin (Cranham i Halle 1985; Scott 1990; Motoba i wsp. 2000; Nauen i wsp. 2001). Od kilku lat także w niektórych rejonach Polski obserwowano obniżenie skuteczności akarycydów z grupy METI (Maciesiak i Olszak 2010). W 2014 roku zaobserwowano w Polsce odporność na akarycydy z grupy METI u przędziorka chmielowca spokrewnionego z przędziorkiem owocowcem występującym często w sadach jabłoniowych w populacjach mieszanych. Obniżoną wrażliwość przędziorka chmielowca na fenpiroksymat wykazano w czterech z siedmiu badanych populacji tego roztocza w sadach jabłoniowych (Gorzka i wsp. 2014).

Celem podjętych badań była ocena wrażliwości przędziorka owocowca na fenpiroksymat $w$ sadach jabłoniowych, zlokalizowanych w różnych rejonach Polski.

\section{Materiały i metody / Materials and methods}

Badania wrażliwości przędziorka owocowca na fenpiroksymat - substancję czynną środka Ortus $05 \mathrm{SC}$, prowadzono w latach 2013-2015 w 7 sadach zlokalizowanych w miejscowościach Michalczowa - woj. małopolskie (populacja kontrolna pochodząca z sadu, w którym nie stosowano chemicznych środków ochrony roślin), Bartodzieje - woj. mazowieckie, Trzylatków Mały - woj. mazowieckie, Białogórne - woj. łódzkie, Dąbrowice - woj. łódzkie, Ostrowiec i Żurawieniec - woj. łódzkie. Osobniki dorosłe przędziorka owocowca pobierano z losowo zebranych liści jabłoni przywiezionych z wybranych sadów na przełomie lipca i sierpnia. Testy wykonano na liściach jabłoni umieszczonych w specjalnie przygotowanych szalkach Petriego (z wywierconym 2,5 cm średnicy otworem $w$ szalce nakrywkowej z naklejonym szyfonem, służącym do wentylacji), podstawka szalki była wyścielona bibułą nasączoną wodą destylowaną. Na liście umieszczone w szalce Petriego nanoszono po 10 osobników dorosłych przędziorka owocowca. Każdą kombinację (lokalizację) testowano w 4 powtórzeniach (40 osobników). Nanoszenie preparatów na liście i znajdujące się na nich przędziorki przeprowadzono w wieży Pottera. Dawkę na hektar przeliczano w stosunku do 1 litra wody, z którego pobierano $2 \mathrm{ml}$ roztworu. Obserwacje nad skutecznością fenpiroksymatu prowadzono w komorze klimatycznej $\left(25^{\circ} \mathrm{C}, 16 \mathrm{~L}\right.$ : 8 D oraz $65 \%$ wilgotność względna). Śmiertelność osobników przędziorka owocowca zebranych w sadach oceniano po 72 godzinach i porównywano ją z osobnikami z populacji kontrolnej. Skuteczność zwalczania przędziorka owocowca obliczono za pomocą wzoru Hendersona-Tiltona. Wyniki opracowano statystycznie za pomocą analizy wariancji (ANOVA). Istotność różnic pomiędzy średnimi oceniono za pomocą testu Newmana-Keulsa przy poziomie istotności $\mathrm{p}=0,05$. Analizy przeprowadzono $\mathrm{w}$ programie STATISTICA v. 13.

\section{Wyniki i dyskusja / Results and discussion}

W 2013 roku, najniższą skuteczność fenpiroksymatu w zwalczaniu przędziorka owocowca stwierdzono w sadzie jabłoniowym w Bartodziejach i wynosiła ona 18\% (tab. 1). W 2014 roku, niską skuteczność na badaną substancję wykazano już w dwóch sadach z sześciu badanych, tj. w miejscowości Ostrowiec oraz w miejscowości Żurawieniec i była ona na poziomie odpowiednio 1,9\% i 5,4\%. W 2015 roku obniżoną wrażliwość przędziorka owocowca na fenpiroksymat wykazano także w dwóch lokalizacjach z czterech badanych, w Bartodziejach (11,8\%) oraz w Ostrowcu $(7,4 \%)$. Przewiduje się, że z powodu wzrostu średnich temperatur, jakie obserwuje się obecnie w Polsce, nie tylko wzrośnie liczebność populacji przędziorka owocowca, ale także zwiększy się liczba pokoleń tego szkodnika w polskich sadach. Proces ten może przebiegać w różnych lokalizacjach z różną intensywnością. Już w 2010 roku pojawiły się w Polsce doniesienia o niezadowalających rezultatach zabiegów zwalczania przędziorka owocowca przy użyciu akarycydów z grupy METI (Maciesiak i Olszak 2010). Zwiększenie tempa rozwoju i wzrost liczby pokoleń z jednoczesną koniecznością zwiększania liczby zabiegów stanowią sytu- 
Tabela 1. Skuteczność fenpiroksymatu w zwalczaniu przędziorka owocowca (Panonychus ulmi, Koch)

Table 1. Efficacy of fenpyroximate in the control of fruit tree European red mite (Panonychus ulmi, Koch)

\begin{tabular}{l|c|c|c}
\hline \multirow{2}{*}{$\begin{array}{c}\text { Lokalizacja } \\
\text { Location }\end{array}$} & \multicolumn{3}{|c}{$\begin{array}{c}\text { Skuteczność zwalczania w latach [\%] } \\
\text { Control of efficacy in years [\%] }\end{array}$} \\
\cline { 2 - 4 } & 2013 & 2014 & 2015 \\
\hline $\begin{array}{l}\text { Michalczowa } \\
\text { (kontrola - control) }\end{array}$ & $100 \mathrm{a}$ & $100 \mathrm{a}$ & 100 \\
\hline Bartodzieje & $18 \mathrm{~b}$ & $* *$ & $11,8 \mathrm{~b}$ \\
\hline Trzylatków Mały & $100 \mathrm{a}$ & $86,3 \mathrm{a}$ & $93,7 \mathrm{a}$ \\
\hline Białogórne & $87 \mathrm{a}$ & $* *$ & $* *$ \\
\hline Dąbrowice & $100 \mathrm{a}$ & $85,4 \mathrm{a}$ & $93,7 \mathrm{a}$ \\
\hline Ostrowiec & $*$ & $1,9 \mathrm{~b}$ & $7,4 \mathrm{~b}$ \\
\hline Żurawieniec & $*$ & $5,4 \mathrm{~b}$ & $* *$ \\
\hline
\end{tabular}

*brak obserwacji - no observation

**brak wystarczającej liczby szkodnika w sadzie do przeprowadzenia testów laboratoryjnych - insufficient pest number in the orchard for laboratory testing

Różne litery w tabeli wskazują na istotność różnic - Different letters in the table indicate the significance of the differences

ację sprzyjającą obniżonej skuteczności środków ochrony roślin. Od czasu pierwszej publikacji w 1951 roku na temat niskiej skuteczności parationu w zwalczaniu P. ulmi, przez kolejne lata obserwowano obniżoną skuteczność na środki owadobójcze i roztoczobójcze, w tym na: związki fosforoorganiczne, dikofol, tetradifon, propargit, cyheksatynę, klofentezynę i heksytiazoks w zaledwie kilka lat po ich wprowadzeniu (Cranham i Halle 1985; Auger i wsp. 2003). Liczne doniesienia wskazują, że w sadach jabłoniowych na świecie, zaobserwowano obniżoną skuteczność na amitraz, dikofol, bromopropylan i fenpyroksymat (Park i wsp. 1986; Fergusson-Kolmes i wsp. 1991; Cho i wsp. 1995) oraz inne środki $\mathrm{z}$ grupy inhibitorów mitochondrialnego transportu elektronów (Nauen i wsp. 2001). W związku z powyższym w strategii zwalczania przędziorków szczególnie ważne jest przestrzeganie zasady przemiennego stosowania środków ochrony roślin z różnych grup chemicznych.

\section{Wnioski / Conclusions}

1. Wykazano obniżoną skuteczność fenpiroksymatu (środek z grupy inhibitorów mitochondrialnego transportu elektronów) w trzech $\mathrm{z}$ sześciu badanych populacji przędziorka owocowca (P. ulmi) pochodzących z sadów jabłoniowych zlokalizowanych w Polsce centralnej.

2. Skuteczna ochrona roślin przed przędziorkiem owocowcem wymaga prowadzenia częstych badań skryningowych nad selektywnością stosowanych przeciw nim środków ochrony roślin z grupy METI.

W pracy wykorzystano wyniki badań uzyskane podczas realizacji tematu statutowego Instytutu Ogrodnictwa nr 4.2.6: „Ocena poziomu odporności przędziorka owocowca ( $\mathrm{Pa}$ nonychus ulmi) na METI akarycydy analizowana w wybranych sadach jabłoniowych w Polsce przy pomocy technik klasycznych i biochemicznych".

\section{Literatura / References}

Auger P., Bonafos R., Guichou S., Kreiter S. 2003. Resistance to fenazaquin and tebufenpyrad in Panonychus ulmi Koch (Acari: Tetranychidae) populations from South of France apple orchards. Crop Protection 22 (8): 1039-1044. DOI: 10.1016/S0261-2194(03)00136-4

Cho J.R., Kim Y.J., Ahn Y.J., Yoo J.K., Lee J.O. 1995. Monitoring of acaricide resistance in field- collected populations of Tetranychus urticae (Acari: Tetranychidae) in Korea. Korean Journal of Applied Entomology 34 (1): 40-45.

Cranham J.E., Halle W. 1985. Pesticide resistance in Tetranychidae. s. 405-421. W: World Crop Pests, Spider Mites, Vol. 1b (W. Halle, M.W. Sabelis, red.). Elsevier, Amsterdam-Oxford-New York-Tokyo, 458 ss.

Fergusson-Kolmes L.A., Scott J.G., Dennehy T.J. 1991. Dicofol resistance in Tetranychus urticae (Acari, Tetranychidae): cross-resistance and pharmacokinetics. Journal of Economic Entomology 84 (1): 41-48. DOI: 10.1093/jee/84.1.41

Gorzka D., Olszak R., Hołdaj M. 2014. Odporność przędziorka chmielowca (Tetranychus urticae, Koch) na METI akarycydy analizowana w wybranych sadach jabłoniowych w Polsce. [Two spotted spider mite (Tetranychus urticae, Koch) resistance to METI acaricides analysed in selected Polish apple orchards]. Progress in Plant Protection 54 (3): 304-307.

Łabanowska H.B., Płuciennik Z., Tartanus M., Warabieda W., Piotrowski W., Hołdaj M., Gorzka D. 2017. Atlas szkodników drzew owocowych. Hortpress Sp. z o.o., Warszawa, 16 ss.

Maciesiak A., Olszak R.W. 2010. Wzrost zagrożenia sadów jabłoniowych przez przędziorka owocowca (Panonychus ulmi Koch) - przyczyny niepowodzeń zwalczania. [Increase of threat of the apple orchards by European red spider mite (Panonychus ulmi Koch) - adversity in control]. Progress in Plant Protection/Postępy w Ochronie Roślin 50 (3): 1292-1296.

Marshall D.B., Pree D.J. 1991. Effects of miticides on the life stages of the European red mite, Panonychus ulmi (Koch) (Acari: Tetranychidae). The Canadian Entomologist 123 (1): 77-87. DOI: 10.4039/Ent12377-1

McMurtry J.A., Huffaker C.B., Van De Vrie M. 1970. Ecology of tetranychid mites and their natural enemies: a review. I. Tetranychid enemies: Their biological characters and the impact of spray practices. Hilgardia 40 (11): 331-390. DOI: 10.3733/hilg.v40n11p331

Motoba K., Nishizawa H., Suzuki T., Hamaguchi H., Uchida M. 2000. Species-specific detoxifcation metabolism of fenpyroximate, a potential acaricide. Pesticide Biochemistry and Physiology 67 (2): 73-84. DOI: 10.1006/pest.2000.2477 
Nauen R., Stumpf N., Elbert A., Zebitz C.P.W., Kraus W. 2001. Acaricide toxicity and resistance in larvae of different strains of Tetranychus urticae and Panonychus ulmi (Acari: Tetranychidae). Pest Management Science 57 (3): 253-261. DOI: 10.1002/ps.280

Park H.M., Choi S.Y., Yoo J.K., Na S.Y., Lee K.H. 1986. Chemical resistance of apple orchard mites (Panonychus ulmi Koch, Tetranychus urticae Koch) and their control with several acaricides. Research Reports of the Rural Development Administration - Plant Environment, Mycology and Farm Products Utilization (Korea Republic) 28 (2): 65-71.

Putman W.L. 1955. Bionomics of Stethorus punctillum Weise (Coleoptera: Coccinelidae) in Ontario. The Canadian Entomologist 87: 9-33.

Scott J.G. 1990. Investigating mechanisms of insecticide resistance: methods, strategies, and pitfalls. s. 39-57. W: Pesticide Resistance in Arthropods (R.T. Roush, B.E. Tabashnik, red.). New York, Chapman \& Hall, 342 ss.

Van se Vrie M., McMurtry J.A., Huffaker C.B. 1985. Biology of tetranyhid mites species occuring on apple. s. 312-314. W: World Crop Pests, Spider Mites, Vol. 1b (W. Halle, M.W. Sabelis, red.). Elsevier, Amsterdam-Oxford-New York-Tokyo, 458 ss. 